\title{
Pemasangan Panel Solar untuk Penerangan Lampu Petani Serai Wangi di Desa Siabu, Salo, Kampar
}

\author{
Azriyenni*1, Amir Hamzah², Fri Murdiya ${ }^{3}$, Suwitno ${ }^{4}$, Pedia Aldy ${ }^{5}$ \\ 1,2,3,4,5 Universitas Riau \\ 1,2,3,4Jurusan Teknik Elektro, Fakultas Teknik, Universitas Riau \\ ${ }^{5}$ Jurusan Teknik Arsitek, Fakultas Teknik, Universitas Riau \\ *e-mail: azriyenni@eng.unri.ac.id
}

\begin{abstract}
Lack of electricity in the rural areas is quite limited to farmers in the lemongrass plantation in Siabu, Salo, Kampar. Their problem provides an idea to assemble solar panels for lighting supplies for lemongrass farmers. The method used for this activity is; field survey, assembly, calibration, and testing. In the test of the battery charging process has been carried out. Batteries charging are utilized 20 Ah and 60 Ah. The solar panels used are 2*50 Wp, Solar Charger Controller, battery, and inverter. The battery of 20 Ah load test results has an electricity of 30 Watt. The maximum battery voltage measured at 12.8 Volt with a load duration of 4 hours. The loading test is also carried out for a battery of $60 \mathrm{Ah}$ has the same load that is a 30 Watt. In this test, the voltage is measured 12.8 Volt, a duration of electricity use for 11 hours.
\end{abstract}

Keywords: battery, lighting, solar panel

\begin{abstract}
Abstrak
Kondisi kelistrikan di pedesaan yang sangat kurang dan terbatas menjadi kendala bagi petani di perkebunan serai wangi di Desa Siabu, Salo, Kampar. Permasalahan di lapangan tersebut memberikan suatu ide dan gagasan untuk merakit panel solar untuk suplai penerangan bagi petani serai wangi. Metode yang dilakukan untuk kegiatan ini adalah survei lapangan, perakitan, kalibrasi alat, dan pengujian lapangan. Pada pengujian telah dilakukan proses pengisian baterai dan pembebanan baterai 20 Ah dan 60 Ah. Panel solar yang digunakan adalah 2*50 Wp, Solar Charger Controller (SCC), Baterai, dan inverter. Hasil pengujian pembebanan baterai 20 Ah memiliki beban listrik lampu 30 Watt, tegangan maksimal baterai yang diukur sebesar 12,8 Volt, dengan durasi pemakaian beban selama 4 jam. Pengujian pembebanan dilakukan juga untuk baterai 60 Ah, dengan beban listrikyang sama yakni lampu 30 Watt, pada keadaan ini tegangan baterai terukur sebesar 12,8 Volt, dengan durasi pemakaian beban listrik selama 11 jam.
\end{abstract}

Kata kunci: baterai, panel solar, penerangan

\section{PENDAHULUAN}

Pemanfaatan energi matahari telah dikembangkan menjadi alternatif yakni pembangkit solar sel. Untuk pembangkit skala rumah sangat berpeluang, terutama di Indonesia adalah kawasan tropis yang berpotensi iradiasi matahari yang selalu ada sepanjang waktu. Adapun konsep kerja teknologi solar sel adalah mengubah energi matahari menjadi energi listrik melalui modul Solar yang berasal dari bahan fotovoltaik (Simanullang et al., 2017)(Azriyenni, 2019). Sistem fotovoltaik ini dengan memanfaatkan energi matahari sebagai sumber daya listrik yang menjadi percontohan penerapan dalam mengembangkan potensi daya kelistrikan secara meluas (M. B. Djaufani, 2015), pengukuran iradiasi matahari di kota Pekanbaru juga telah dilakukan (Amanda Khaira Perdana \& Hasyim Rosma, 2017). Desa Siabu Kecamatan Salo yang terletak di Kabupaten Kampar memiliki perkebunan serai wangi dengan luas delapan hektar, kebun tersebut dikelola oleh salah seorang petani dari di desa setempat bersama tiga orang petani yang membantunya. Petani serai wangi ini mengelola dan mengolah hasil serai wangi dalam kelompok mereka sendiri. Adapun pengolahan daun serai wangi ini disuling menjadi menjadi minyak serai wangi. Penyulingan minyak serai wangi ini karena lamanya dilakukan hingga malam hari. Namun, keadaan di perkebunan tersebut jauh dari jangkauan listrik PT. PLN (Persero), sehingga petani tersebut mengalami keterbatasan aktifitas dalam produksi. Oleh karena permasalahan tersebut, 
pemasangan panel solar ini sangat dibutuhkan untuk menunjang segala aktifitas produksi petani serai wangi di Desa Siabu.

Beberapa tinjauan kepustakaan yang terkait dengan penerapan panel solar untuk digunakan sebagai sumber energi listrik seperti dipaparkan berikut ini; K. Mizuki telah melakukan menerapkan tentang spesifikasi struktur fotovoltaik dan pengontrolan sistem daya listrik DC tanpa jaringan listrik. Penelitian ini memberi fokus sistem daya listrik dengan pembangkit listrik tenaga surya. Penerapan usulan ini menghasilkan pemilihan biaya solar sel mendapatkan sistem hasil yang sangat efektif untuk penyaluran daya listrik untuk jangka panjang dan berkelanjutan (K. Mizuki, 2014). Hasyim Asy'ari A, telah menerapkan pula penggunaan solar sel untuk menyuplai beban lampu penerangan rumah dengan dua buah panel solar pada nilai setiap panel $100 \mathrm{Wp}$. Beban listrik yang digunakan adalah lampu $5 \mathrm{Watt}, 10 \mathrm{Watt}, 13$ watt dan lampu 5 buah 18 Watt. Sistem yang digunakan adalah hibrid yakni; jika beban disuplai oleh pembangkit listrik solar sel maka secara otomatis suplai dari PLN terlepas (Hasyim Asy'ari, A. R., 2014). Nahdia Rupawanti BR telah menerapkan PJU di Kecamatan Mantup Kabupaten Lamongan menggunakan panel surya berkapasitas $150 \mathrm{Wp}$ dan lampu $40 \mathrm{Watt}$. Efisiensi daya dari panel modul solar sel sebesar 18\% ditentukan oleh posisi kemiringan dari panel solar sel dan intensitas cahaya matahari (BR, 2017). Kemudian, W. Anhar telah pula melaksanakan Pengabdian Kepada Masyarakat (PKM) Kelurahan Sepinggan di Balikpapan bagi penerapan lampu jalan umum berbasis solar sel. Langkah kerja mereka terdiri dari observasi, perencanaan, penerapan, dan pengujian. Komponen yang digunakan adalah; lampu PJU DC LED, solar panel, regulator, dan baterai. Hasil kegiatan mereka diperoleh dengan penerapan lampu DC LED 12 V-12 W, baterai 35 Ah-12V, solar panel $100 \mathrm{Wp}$, dan SCC 10 A dengan lama penggunaan selama 12 jam (Anhar et al., 2018). Dari tinjauan pustaka tersebut diatas, maka kegiatan pengabdian ini dijalankan disesuaikan dengan permasalahan dan kebutuhan yang dihadapi oleh petani serai wangi di desa Siabu. Dengan merujuk berbagai metode yang telah diuraikan diatas, maka kegiatan pengabdian masyarakat ini bertujuan untuk menerapkan hasil penelitian bidang konservasi energi dalam bentuk Teknologi Tepat Guna (TTG). Selanjutnya, kegiatan pengabdian kepada masyarakat ini ditaja oleh Lembaga Penelitian Masyarakat, Universitas Riau.

\section{METODE}

Beberapa metode telah dilakukan oleh para peneliti dan praktisi tahun sebelumnya, diantaranya yakni; metode dual-axis photovoltaic tracking system (Seme et al., 2017), metode skema sistem panel solar menggunakan MPPT (Hamed Nademi, L. E. N., 2017), memodelkan sistem panel solar dengan menggunakan perangkat Matlab/Simulink (Zakri et al., 2018), metode pengisian baterai dengan sumber solar sel menggunakan arduino (Azriyenni A.Z, Hanggun S, Salhazan N, 2019). Metode yang dilakukan untuk kegiatan ini adalah survei lapangan, perakitan, kalibrasi alat, dan pengujian lapangan. Pada pengujian ini akan dilakukan proses pengisian baterai dan pembebanan baterai $20 \mathrm{Ah}$. Bahan yang digunakan diantara panel solar $2 * 50 \mathrm{Wp}$, Solar Charger Controller (SCC), Baterai, dan inverter. Kemudian, beban listrik yang digunakan Lampu 16 Watt, Kipas Angin 46 Watt. Proses pengisian dilakukan menggunakan panel surya menggunakan dua panel $50 \mathrm{Wp}$ di pasang paralel dan untuk pembebanan menggunakan peralatan listrik rumah tangga dengan daya yang bervariasi. Pada pengujian ini telah dilakukan proses pengisian baterai dan pembebanan baterai $20 \mathrm{Ah}$. Gambar 1 adalah skema rangkaian pengisian baterai dengan panel solar terpasang $2 * 50 \mathrm{Wp}$. Proses pengisian dilakukan menggunakan panel solar menggunakan dua panel $50 \mathrm{Wp}$ yang dipasang secara paralel, dan untuk pembebanan menggunakan peralatan listrik rumah tangga dengan daya yang bervariasi. 


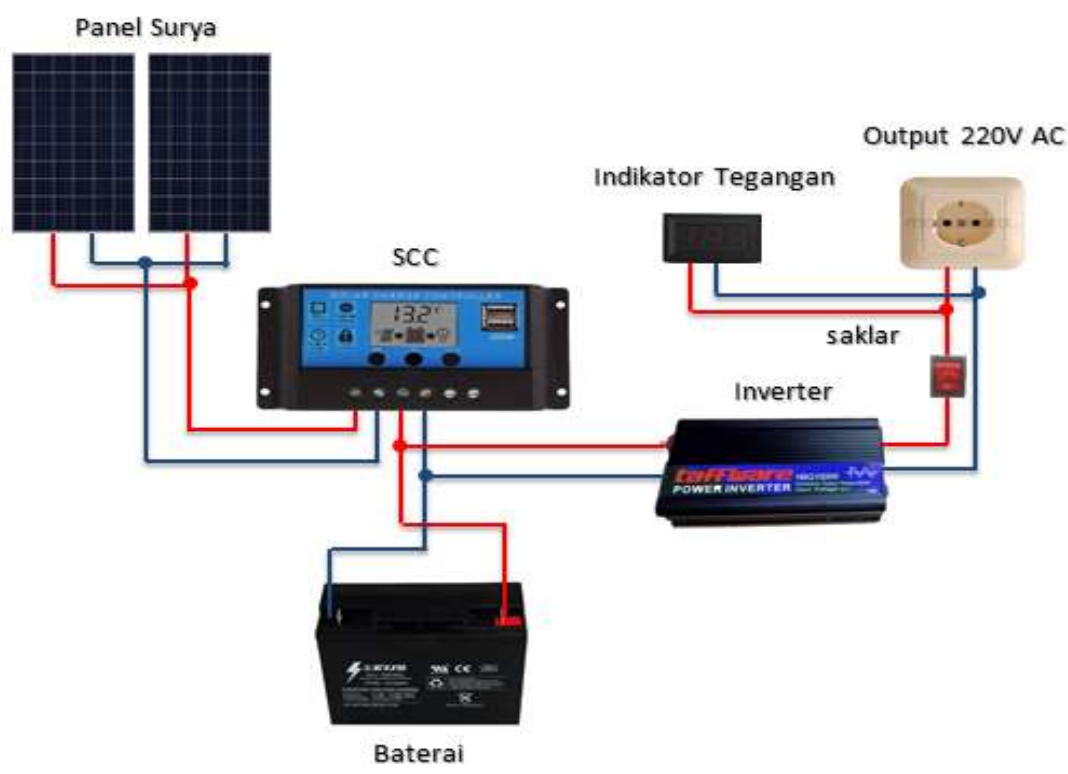

Gambar 1. Skema rangkaian sistem panel solar

Gambar 1 menunjukkan skema panel solar berfungsi mengkonversi energi matahari menjadi energi listrik dapat digunakan untuk pengisian baterai. Energi dari panel solar disalurkan ke baterai dikontrol oleh SCC, kemudian dikontrol proses pengisian baterai untuk melindungi baterai dari over charging. Untuk menggunakan energi baterai ke peralatan listrik maka digunakan inverter untuk mengubah energi listrik DC menjadi AC 220V. Untuk memutus dan menghubungkan energi listrik ke beban, maka digunakan sebuah saklar dan tegangan keluaran dari inverter dapat dilihat pada indikator tegangan. Gambar 2 adalah proses pemasangan panel solar dikawasan kebun sekaligus pondok penyulingan petani serai wangi, dengan kapasitas panel solar $2 * 50 \mathrm{Wp}$ terkoneksi secara paralel, kemiringan panel sebesar 40 derajat, tinggi tiang penyangga adalah 2,5 meter. Sementara untuk SCC, baterai dan inverter dipasang didalam rumah petani. Tabel 1 adalah detail spesifikasi dari panel solar yang dipergunakan pada kegiatan pengabdian ini, spesifikasi ini ingin menunjukkan parameter nominal yang dipergunakan untuk panel solar ini, tegangan terbuka yang dipergunakan adalah 21,8 Volt dan arus hubung singkat sebesar 3,03 Ampere.

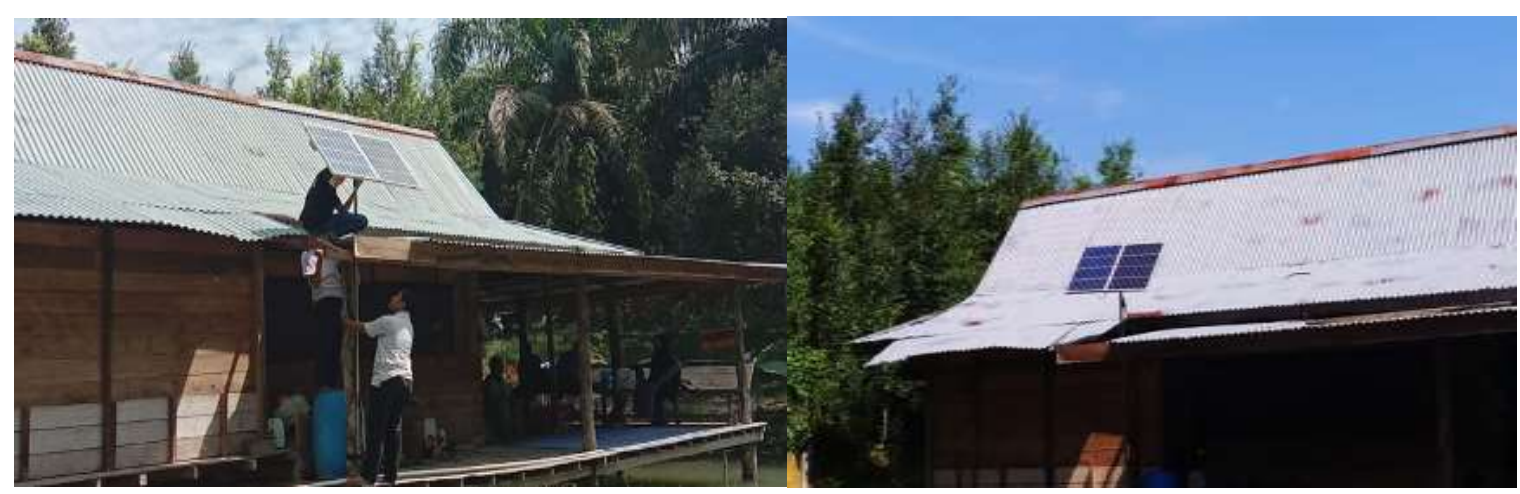

Gambar 2. Pemasangan solar panel dikawasan perkebunan petani serai wangi 
Tabel 1. Spesifikasi panel solar $50 \mathrm{Wp}$

\begin{tabular}{lc}
\hline Model Panel & SP050-18P \\
Peak Power (Pmax) & $50 \mathrm{~W}$ \\
Cell Efficicncy & $16,93 \%$ \\
Max. Power Volt (Vmp) & $17,8 \mathrm{~V}$ \\
Max. Power Current (Imp) & $2,81 \mathrm{~A}$ \\
Open Circuit Volt (Voc) & $21,8 \mathrm{~V}$ \\
Short Circuit Current (Isc) & $3,03 \mathrm{~A}$ \\
Power Tolerance & $\pm 3 \%$ \\
Max. System Voltage & $1000 \mathrm{~V}$ \\
Series fuse rating (A) & 12 \\
Number of bypass dioda & 1 \\
Operating Temperature & $-45^{\circ} \mathrm{C}-+85^{\circ} \mathrm{C}$ \\
Max. System Voltage & $1000 \mathrm{~V} \mathrm{DC}$ \\
Irradiance & $1000 \mathrm{~W} / \mathrm{m}^{2}$ \\
\hline
\end{tabular}

\section{HASIL DAN PEMBAHASAN}

Hasil pengujian pada proses pengisian baterai melalui panel solar menggunakan dua buah baterai yaitu; baterai $20 \mathrm{Ah}$ dan baterai $60 \mathrm{Ah}$. Tegangan awal baterai di ukur sebelum baterai diisi dan tegangan akhir baterai diukur beberapa saat setelah baterai diisi dalam waktu tertentu. Setelah baterai diisi, maka tidak bisa langsung mengukur tegangan baterai sebab tegangan baterai belum stabil, nilai tegangan yang masih tinggi perlahan akan menurun sampai mencapai nilai yang konstan yaitu nilai tegangan baterai sebenarnya. Tabel 2 adalah cuplikan pengisian baterai 20 Ah yang dimulai jam 8:30 sampai 12:50 sekitar 4 jam 20 menit, dengan nilai tegangan dimulai dari posisi baterai 11,7 Volt (minimum) sampai 12,8 Volt (maksimum), dengan iradiasi $809 \mathrm{~W} / \mathrm{m}^{2}$, dan temperatur panel solar $34^{\circ} \mathrm{C}$ sampai $42^{\circ} \mathrm{C}$. Ada beberapa faktor yang menyebabkan arus tiba-tiba drop, yang mempengaruhi oleh kondisi cuaca cerah tapi berawan, maka tingkat iradiasi menjadi turun seperti pada jam 11:00 siang. Hasil pengujian pembebanan baterai 20 Ah dengan beban listrik lampu 30 Watt, tegangan maksimal baterai yang diukur sebesar 12,8 Volt, dengan durasi pemakaian selama 4 jam. Pengujian pembebanan dilakukan pula pada baterai 60 Ah dengan beban listrik yang sama yakni lampu $30 \mathrm{Watt}$, pada keadaan ini tegangan baterai terukur sebesar 12,8 Volt dengan durasi pemakaian arus listrik selama 11 jam. Tegangan baterai yang diukur beberapa saat setelah beban dilepas/dimatikan sampai alaram inverter berbunyi. Kemudian, setelah diamati semakin besar daya beban yang digunakan maka durasi pemakaiannya makin kecil, sehingga jika ingin pemakaian sumber listrik lebih lama maka gunakan daya beban yang lebih kecil. Gambar 3 adalah box panel yang dipasang didalam rumah, dirancang untuk memudahkan pengontrolan dan pemasangan instalasi listrik supaya lebih aman. Box panel ini terdiri dari; SCC, inverter, stop kontak, saklar dan lampu indikator. Juga dapat menampilkan indikator tegangan keluaran AC. Gambar 4 menunjukkan keadaan pembebanan secara langsung dan nyata pada keadaan malam hari yang digunakan oleh petani serai wangi di Desa Siabu, Kecamatan Salo, Kampar. 
DINAMISIA: Jurnal Pengabdian Kepada Masyarakat

Tabel 2. Pengisian baterai dengan tegangan awal 11,7 Volt dan tegangan akhir 12,8 Volt pada kapasitas panel solar $2 * 50 \mathrm{Wp}$

\begin{tabular}{|c|c|c|}
\hline Waktu & $\begin{array}{c}\text { Iradiasi } \\
\text { Matahari } \\
(\mathrm{W} / \mathrm{m} 2)\end{array}$ & $\begin{array}{c}\text { Temperatur } \\
\text { Panel }\left({ }^{\circ} \mathrm{C}\right)\end{array}$ \\
\hline $08: 30$ & 739 & 34 \\
\hline $08: 40$ & 769 & 34 \\
\hline $08: 50$ & 817 & 36,2 \\
\hline 09:00 & 785 & 36,2 \\
\hline 09:10 & 518 & 34 \\
\hline 09:20 & 781 & 34 \\
\hline 09:30 & 906 & 37 \\
\hline 09:40 & 979 & 37 \\
\hline 09:50 & 1.059 & 37,2 \\
\hline $10: 00$ & 986 & 36 \\
\hline $10: 10$ & 1.078 & 36 \\
\hline $10: 20$ & 1.110 & 36 \\
\hline $10: 30$ & 710 & 38,2 \\
\hline $10: 40$ & 924 & 38,2 \\
\hline $10: 50$ & 674 & 38,2 \\
\hline $11: 00$ & 342 & 38,2 \\
\hline $11: 10$ & 477 & 36 \\
\hline $11: 20$ & 948 & 38,2 \\
\hline $11: 30$ & 1.115 & 34 \\
\hline $11: 40$ & 1.037 & 38 \\
\hline $11: 50$ & 808 & 36 \\
\hline $12: 00$ & 973 & 38 \\
\hline $12: 10$ & 731 & 38,2 \\
\hline $12: 20$ & 795 & 38,2 \\
\hline $12: 30$ & 374 & 42 \\
\hline $12: 40$ & 716 & 40 \\
\hline $12: 50$ & 702 & 42 \\
\hline
\end{tabular}
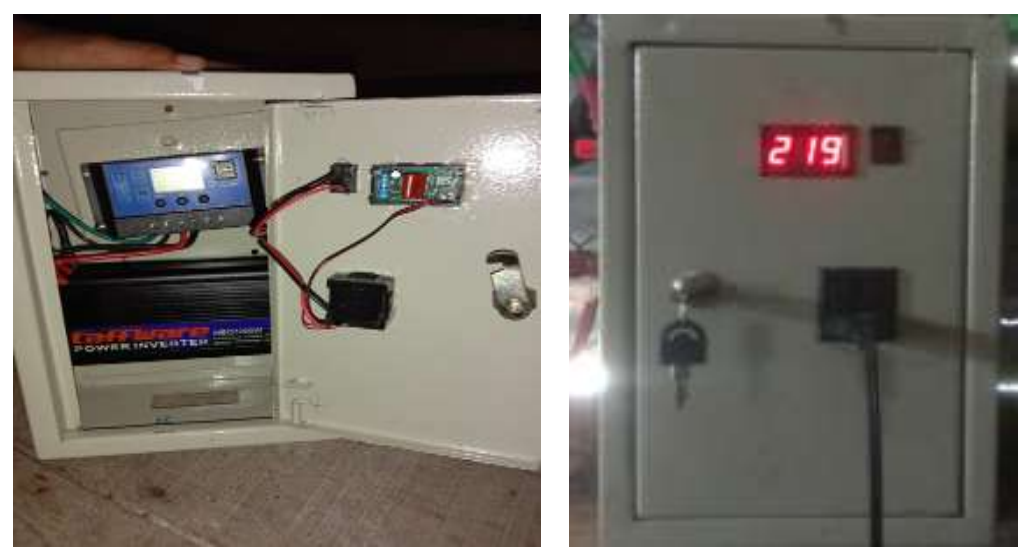

Gambar 3. Box panel dipasang di dalam pondok petani serai wangi 


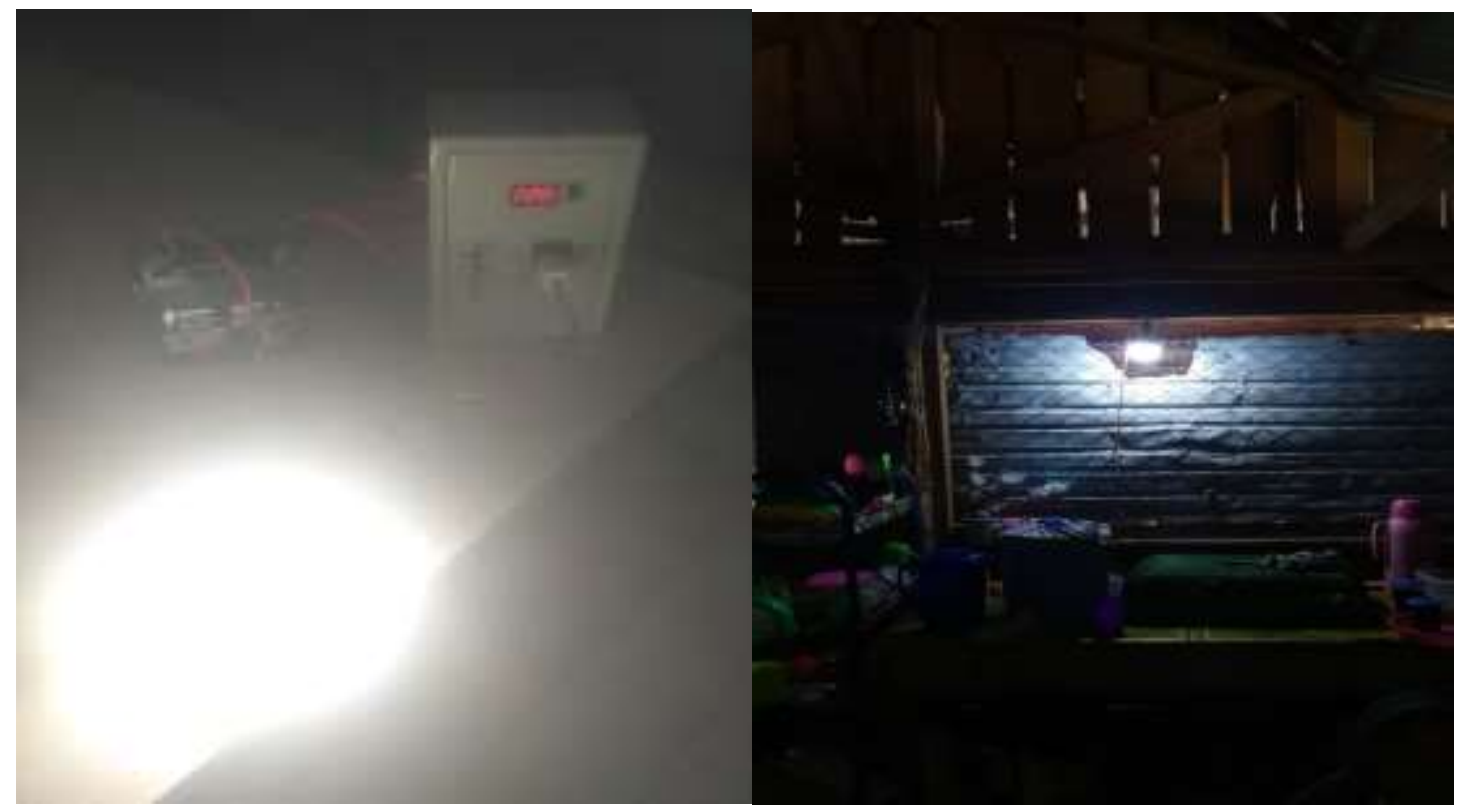

Gambar 4. Pengujian beban lampu di pondok petani serai wangi desa Siabu

\section{KESIMPULAN}

a) Dengan adanya pemasangan solar panel dikawasan perkebunan petani serai wangi di Desa Siabu, Kecamatan Salo, Kampar ini sangat membantu sekali bagi para petani yang jauh dari jangkauan listrik PLN.

b) Penyerapan intensitas iradiasi matahari sangat memiliki potensi yang bagus pada kawasan perkebunan yang agak tinggi, sehingga penyerapan energi matahari ke permukaan panel solar menghasilkan daya yang maksimal.

c) Pemasangan sudut kemiringan panel solar dengan sudut kemiringan $40^{\circ}$ dari posisi tegak lurus terhadap sinar datang matahari dapat membangkitkan daya keluaran panel fotovoltaik lebih besar.

d) Besarnya nilai kapasitas baterai menentukan daya simpan baterai, makin besar kapasitas baterai maka semakin besar daya simpannya. Dengan tegangan baterai yang menunjukkan kondisi baterai berkisar pada rentang tegangan 12,7 Volt - 13 Volt dalam keadaan tanpa beban dan tergantung jenis baterai serta temperatur baterai.

\section{UCAPAN TERIMA KASIH}

Penulis mengucapkan terima kasih kepada Lembaga Penelitian dan Pengabdian Masyarakat (LPPM) Universitas Riau yang telah memberi dukungan Hibah DIPA-UNRI 2020 terhadap skema pengabdian Kepada Masyarakat ini.

\section{DAFTAR PUSTAKA}

Amanda Khaira Perdana, \& Hasyim Rosma, I. (2017). Analisis Kalibrasi Sensor BH1750 Untuk Mengukur Radiasi Matahari Di Pekanbaru. SeMNASTeK 2017, 1-6.

Anhar, W., Akbar, S., Laksito, A., Huda, N., Mesin, J. T., Balikpapan, P. N., Administrasi, J., Publik, K., Isipol, F., \& Tridharma, U. (2018). Penerapan Lampu Penerangan Jalan Umum Berbasis Solar System di RT 50 Kelurahan Sepinggan Kota. KACANEGARA Jurnal Pengabdian Pada Masyarakat, 67-74. 
Azriyenni. (2019). Teknik ANFIS untuk Prediksi Sistem Fotovoltaik. Indomedia Pustaka.

Azriyenni A.Z, Hanggun S, Salhazan N, N. (2019). Alat Otomatis Pengisi Baterai Bersumber Solar Sel Menggunakan Pengendali Arduino.

BR, N. R. (2017). Analisis Dan Efisiensi Daya Instalasi Penerangan Jalan Umum Menggunakan Solar Cell di Kabupaten Lamongan. Jurnal Elektro, 2(2), 7. https://doi.org/10.30736/je.v2i2.80

Hamed Nademi, L. E. N., S. W. (2017). An Accurate MPPT Scheme for Photovoltaic Modular Based Conversion Units: A Robust Sensorless Predictive Approach.

Hasyim Asy'ari, A. R., F. S. P. (2014). Pemanfaatan Solar Cell dengan PLN Sebagai Sumber Energi Listrik Rumah Tinggal. Jurnal Emitor.

K. Mizuki, H. Y. (2014). Maximizing Power-Supply Time Of Dc Power System With Photovoltaics And Fuel Cells. IEEE.

M. B. Djaufani, N. H. (2015). Perancangan Dan Realisasi Kebutuhan Kapasitas Baterai Untuk Beban Pompa Air 125 Watt Menggunakan Pembangkit Listrik Tenaga Surya. Jurnal Reka Elkomika, $3(2), 75-86$.

Seme, S., Srpčič, G., Kavšek, D., Božičnik, S., Letnik, T., Praunseis, Z., Štumberger, B., \& Hadžiselimović, M. (2017). Dual-axis photovoltaic tracking system - Design and experimental investigation. Energy, 139.

Simanullang, D. P. H., Zakri, A. A., Teknik, F., Program, D., Teknik, S., \& Teknik, F. (2017). Perancangan Energi Listrik Berbasis Fotovoltaik untuk Alat Rumah Tangga Berkapasitas 150 Watt. SeMNASTeK.

Zakri, A. A., Nurhalim, N., Simanulang, D. P. H., \& Tribowo, I. (2018). Photovoltaic Modeling Methods Based on Matlab Simulink Implementation. Sinergi, 22(1). 